\title{
Os pais da Igreja enquanto apologetas da teologia natural e da filosofia da religião na modernidade nascente
}

\author{
Dr. habil. Günter Frank* \\ Tradução: Eduardo Gross*
}

\section{Resumo}

A filosofia da religião moderna se desenvolveu a partir de reflexões prévias que nem sempre são bem conhecidas. Até que ela assumisse um ponto de vista crítico, no sentido iluminista, a abordagem filosófica da tradição teológica foi arduamente discutida. Durante a Renascença, a filosofia antiga e tradições especulativas foram comparadas aos Pais da Igreja a partir do ponto de vista de uma philosophia perennis. Nesse processo, os limites da abordagem geral prepararam o caminho para a modernidade.

Palavras-chave: Filosofia da religião; philosophia perennis; renascimento; patrística; apologética

\section{Church Fathers as Apologists for Natural Theology and Philosophy of Religion in Early Modernity}

\begin{abstract}
Modern Philosophy of Religion developed from previous reflections which are not always well known. Until it assumed a critical point of view, in the sense of the Enlightenment, the philosophical approach to theological tradition was heavily discussed. During Renaissance, ancient philosophy and speculative traditions were compared to the Church Fathers, from the point of view of a philosopbia perennis. In this
\end{abstract}

* Graduações em psicologia, teologia e filosofia; doutorado em filosofia pela Pontíficia Universidade Gregoriana; habilitação pela Universidade Livre de Berlim; professor extraordinário de filosofia no Karlsruhe Institut für Technologie; diretor da Europäische Melanchthon-Akademie Bretten. E-mail:dr.frank@melanchthon.com; currículo resumido: https://www.philosophie.kit.edu/324.php.

** Graduação e Doutorado em Teologia pela EST-RS; Professor da UFJF, com atuação nos Programas de Pós-Graduação em Ciência da Religião e Filosofia e-mail: eduardo.gross@ufff.edu.br; currículo: http://lattes.cnpq.br/2654429053268264. 
process, the shortcomings of the general approach prepared the path for Modernity.

Keywords: Philosophy of religion; philosophia perennis; Renaissance; Patristic; apologetic

\section{Los Padres de la Iglesia como apologistas de la Teología Natural y la Filosofía de la Religión en la Naciente Modernidad}

\section{Resumen}

La moderna filosofía de la religión se desarrolló a partir de reflexiones previas, las cuales ni siempre son bien conocidas. Hasta que se asumiera un punto de vista crítico, en el sentido iluminista, el abordaje filosófico de la tradición teológica fue muy debatido. Durante el Renacimiento, la filosofía antigua y las tradiciones especulativas fueron comparadas a los Padres de la Iglesia desde el punto de vista de una philosophia perennis. En este proceso los límites del abordaje general prepararan el camino a la modernidad. Palabras-llave: Filosofía de la religión; philosophia perennis; renacimiento; patrística; apologética

\section{Os pais da Igreja enquanto apologetas da teologia natural e da filosofia da religião na modernidade nascente ${ }^{1}$}

I.

Sem entrar na discussão referente a uma conceituação daquilo que poderia ter sido a intenção da filosofia da religião enquanto disciplina científica nos séculos 19 e 20 e sem aqui já ter de remeter à primeira Philosophy of Religion de Ralph Cudworth, a reflexão filosófica sobre a religião em um sentido geral pode ser caracterizada como a questão pela possibilidade de se pensar a ideia de Deus. Esta perspectiva filosófica se origina já a partir dos esboços da Antiguidade que tiveram maior importância em termos de efeitos históricos. A partir de Aristóteles e do aristotelismo, isto está ligado principalmente à definição temática da metafísica enquanto disciplina científica primeira e geral. Pois, por um lado, eram para ele tema da metafísica as causas do ser enquanto ser, que em última instância são idênticas com o divino (ARISTÓTELES, Metafísica E 1, 1025 1-1026a 23.). Por outro lado, entretanto, Aristóteles também tinha definido a metafísica enquanto ciência

A pesquisa, que no alemão leva o título “Die Kirchenväter als Apologeten der natürlichen Theologie und Religionsphilosophie in der frühen Neuzeit”, faz parte da coleção In: FRANK, Günter; LEINKAUF, Thomas; WRIEDT, Markus (ed.) Die Patristik in der Frühen Neuzeit: die Relektüre der Kirchenväter in den Wissenschaften des 15. bis 18. Jahrhunderts. Friedrich Frommann Verlag Gunther Holzboog, 2006. Melanchthon Schriften der Stadt Bretten, Bd. 10. 
dos fundamentos e dos princípios do ser no sentido de uma ontologia universal (ARISTÓTELES, Metafísica $\Gamma$ 1, 1003a). Para o conceito aristotélico de metafísica enquanto ciência primeira e mais geral, é característico em um sentido fundamental que esta é sempre simultaneamente ontologia e teologia. Esta concepção, em cujos centro está, pois, uma ideia filosófica de Deus, resultou da reivindicação da metafísica enquanto a disciplina mais geral ${ }^{2}$. Pois caso os princípios últimos do ser não estivessem em qualquer relação com o fundamento divino enquanto tema da teologia, isto redundaria em uma particularidade de ambas disciplinas e a reivindicação da metafísica enquanto disciplina mais geral seria falha por princípio.

Ainda mais manifesto é naturalmente o caráter teológico do platonismo. Já o mito da criação no Timen era muito mais harmonizável com a doutrina cristã da criação do que a doutrina aristotélica da eternidade do mundo. Mas Platão tinha antes de tudo definido Deus como o bem e como um

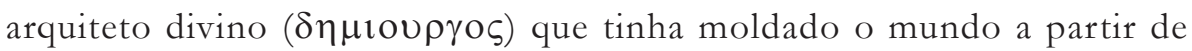
ideias e princípios ${ }^{3}$. Não menos influente - principalmente para a discussão na modernidade nascente - foi por fim a naturalização da ideia de Deus, tal como Marcus Túlio Cícero a tinha apresentado no seu escrito De natura deorum (surgido em 44 a. C.). Pois aqui Cícero ensinou que está impresso nas almas das pessoas não só o conhecimento da existência dos deuses, o que desde Epicuro era chamado de $\pi \rho 0 \lambda \eta \psi \imath \iota$, mas da mesma forma a beatitude e a eternidade dos deuses ${ }^{4}$.

É claro que estas considerações relativas a uma ideia filosófica de Deus, tal como elas foram formuladas já na filosofia da Antiguidade, estão em uma certa tensão em relação com a ideia de Deus da teologia revelada, a qual, ex definitione, justamente se fecha ao acesso do esforço humano da razão. Esta tensão já se mostrava também entre as posições entrementes contrapostas dos pais da Igreja. Enquanto que Justino (falecido por volta de 65) com a

2 Para a discussão dessa problemática, cf. FLASHAR, 1983, principalmente p. 376-381.

3 Timen 29a, 1-3; 29d, 5-30a, 4; 31c, 1-32c, 6. O discurso do arquiteto divino se encontra em $29 \mathrm{a}, 3$.

4 CICERO, De natura deorum I, 43: "Só ele (Epicuro) reconheceu, primeiro, que os deuses permanecem porque a própria natureza imprimiu a concepção deles em todas as almas. Onde há um povo ou uma tribo humana que, mesmo sem instrução, não possua uma concepção dos deuses? Epicuro a chama de $\pi \rho 0 \lambda \eta \psi \imath \varsigma$, isto é, um conhecimento précompreendido pela mente, sem o qual não se pode entender nem examinar ou debater algo." I, 45: "A mesma natureza que nos possibilitou o próprio conhecimento dos deuses também inculcou em nossas almas que nós os consideramos eternos e bem-aventurados." Citado de CICERO, 1990, aqui p. 48s. 


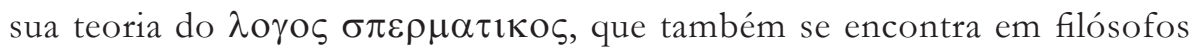
e poetas não cristãos, parecia lançar uma ponte entre o Cristianismo e a filosofia (1. Ap. 46; 2. Ap. 8; 13), Tertuliano (meados do século 2, por 222) é considerado como exemplo para uma rejeição abrupta do pensar filosófico na teologia com vistas à preservação da autonomia da teologia revelada (De praescr. haeret. 7, 9; CCL 1, 193).

Esta tensão entre a ideia de Deus da filosofia e da teologia revelada também pode ser encontrada entre os eruditos latinos da Idade Média. Pois diferentemente da polêmica anti-escolástica posterior, era necessário para estes teólogos, no contexto do avanço da metafísica aristotélica através de eruditos árabes como Avicena e Averrois, definir de forma nova a fronteira entre a ideia de Deus da filosofia e a da teologia revelada. Do contrário - como várias teses das condenações doutrinárias de 1277 advertiam - a teologia se diluiria em filosofia. Os esboços de direcionamento de um Tomás de Aquino, de um João Duns Scotus, de um Guilherme de Ockham, mas também de um Mestre Eckard ${ }^{5}$, eram simultaneamente tentativas de redefinir as fronteiras da metafísica a fim de poderem mostrar que uma teologia revelada é possível e necessária. Através de argumentação filosófica se exercia crítica do conhecimento e da metafísica. "Em síntese, a sua própria tarefa leva a teologia a uma crítica da metafísica, a qual não pode ser realizada por outro modo do que como metafísica." (HONNEFELDER, 1996, p. 169).

No que diz respeito à Idade Média tardia foi afirmada de vários modos uma ruptura entre teologia e filosofia, entre uma ideia filosófica e uma teológica de Deus. De maneira marcante Wilhelm Weischedel tinha formulado isto da seguinte forma: Ao "final da Idade Média a confiança na razão natural desmorona.” Uma fuga em direção à fé teria sido o pressuposto para a rejeição da filosofia por Lutero, a qual - após um interlúdio com Melanchthon e a escolástica protestante - dominou o protestantismo até o presente (WEISCHEDEL, 1979, p. 145). Este juízo generalizado naturalmente não se sustenta desta forma nem para a Idade Média tardia, nem para a modernidade nascente em seu conjunto. Mas de fato as advertências para não se misturar a teologia com a filosofia são impossíveis de não ser percebidas. O erudito francês João Gerson (1363-1429), tão influente na teologia medieval tardia, discípulo de Pedro d'Ailly, não se cansava de advertir a respeito da 5 Aqui se remete principalmente aos resultados da última conferência sobre Mestre Eckard,
de 23 a 28 de setembro em Erfurt [cf. SPEER, Andreas; WEGENER, 2005.]. 
assunção da filosofia no debate teológico ${ }^{6}$. Mesmo o professor de Martim Lutero para filosofia em Erfurt, Bartolomeu Arnoldi de Usingen (por volta de 1465-1532), participava desse coro, de tal forma que já por parte de contemporâneos tinha lhe sido feita a acusação de ter rompido com a escolástica ${ }^{7}$. Mas os seus motivos crítico-filosóficos nunca o tinham levado até o ponto de rejeitar abruptamente a filosofia em favor da teologia. E mesmo em relação ao erudito ockhamista de Tübingen Gabriel Biel (por volta de 1410-1495), que tinha sido objeto de discussão constante em conexão com a teologia reformatória, não é possível encontrar um pessimismo cognitivo resignado no que diz respeito a uma ideia filosófica de Deus ${ }^{8}$.

\section{II.}

Para a discussão sobre filosofia da religião na modernidade nascente é possível distinguir no mínimo quatro diferentes perspectivas de efetivação. Naturalmente, em primeiro lugar deve aqui ser citado Martim Lutero, cujos motivos de crítica filosófica levaram a discussões de monta no período posterior ${ }^{9}$. Aqui devem ser referidas primeiro as suas Conclusiones contra scholasticam theologiam de 1517 (WA 1, 224-228), as quais Lutero não só utilizou como ocasião para rejeitar a ética aristotélica, mas cuja crítica Lutero também quis ver estendida para toda a relação com o conjunto da filosofia ${ }^{10}$. Ao lado das probationes para as "teses filosóficas da disputação de Heidelberg" de $1518^{11}$ e da Disputatio de homine de $1536^{12}$, deve-se referir aqui principalmente a sua famosa disputação sobre João 1.14 de 11 de janeiro de 1539 (verbum caro factum est - WA 39/2, 3-5), na qual Lutero discute a relação entre teologia e filosofia com toda clareza no contexto da doutrina de uma dupla verdade desde as condenações doutrinárias de Paris de 1277. Sem poder aqui analisar detalhadamente esta disputatio (FRANK, 2003, capítulo I.), que seja feita referência aqui somente à mais importante conclusão: Mesmo que -

\footnotetext{
Cf. a respeito a referência com literatura complementar em BURGER, 2002, p. 217-219. Cf. a respeito das posições filosóficas de Arnoldi quanto a estas questões, com as demonstrações correspondentes, o estudo do autor: FRANK, 2003, principalmente p. 41-43, $47 \mathrm{~s}$.

8 Detalhadamente quanto a isso, ERNST, 1972.

9 Cf. quanto ao que segue em detalhe, cf. o estudo do autor, FRANK, 2003, capítulo I.

10 Cf. quanto a isso MOSTERT, 1985, p. 347-368; e em detalhe, DIETER, 2001.

11 A edição do texto se encontra em JUNGHANS, 1979, p. 34-57.

12 WA 39, I, 174-177. Detalhadamente, quanto a isso, ver EBELING, 1977-1989.
} 
como a pesquisa mais recente largamente comprovou - na assim chamada doutrina da "dupla verdade" de certo se trata de uma lenda da Idade Média, esta de fato foi aplicada na tentativa de defender e fundamentar a autonomia do pensamento filosófico contra uma reivindicação de verdade teológica feita por pretensos eruditos. Em Lutero ocorre exatamente o oposto: ele defende a autonomia e a superioridade da teologia revelada em relação à filosofia e procura empregar em uma tal concepção a doutrina de uma duplex veritas. A questão relativa a uma duplex veritas, à qual também sempre tinha pertencido a possibilidade de uma ideia filosófica de Deus, conduziria a partir de agora às discussões mais plenas de consequências, e encontraria seu ápice provisório na famosa querela de Hoffmann, por volta da virada para o século 17, em que o teólogo de Helmstedt Daniel Hoffmann (1538-1611) se reportou para a defesa da doutrina de uma dupla verdade a ninguém menos do que ao próprio Lutero (HOFFMANN, 1600).

Os dois outros reformadores, Filipe Melanchthon e João Calvino - e esta é a segunda perspectiva de efetivação no século 16 - tomaram nessa questão uma outra posição. Ambos ensinaram a possibilidade de uma ideia de Deus em conexão com a doutrina da Trindade, a qual eles fundamentaram com considerações neoplatônico-ciceronianas, uma posição que se designa na pesquisa com o conceito nada belo de "inatismo". ${ }^{13}$ Assim Deus teria impresso no espírito humano, por ocasião da criação, como expressão de uma imagem divina estrutural perene, princípios naturais da existência e da essência divinas. Em Melanchthon - só para mencionar um exemplo dentre tantos em suas manifestações - isso significa que "também agora, após a queda no pecado, o Espírito e as verdadeiras notitiae (são) testemunhas na mente de que Deus existe e de que ele é um ser inteligente, verdadeiro, bom, justo, benevolente, puro, castigador dos ímpios, etc."14. Uma posição semelhante se encontra nas Instituitiones christianae religionis do reformador genebrino do ano de 1559 . Aqui Calvino discute detalhadamente nos primeiros cinco capítulos o inatismo neoplatônico (Dei notitia mentibus nostris insita). Esta convicção geral de uma ideia naturalizada de Deus na mente da pessoa, em favor da qual

\footnotetext{
13 Quanto a Melanchthon, cf. para detalhadamento o estudo do autor: FRANK, 2003. Para além disso, quanto a Melanchthon e Calvino, o capítulo I.

14 CR 12, 591f: “[...] nunc post lapsum tamen mens et verae notitiae in mente testimonia sunt, quod sit Deus et quod sit essentia intelligens, vera, bona, iusta, benefica, casta, vindex scelerum etc."
} 
ele, como anteriormente Melanchthon, remete a Cícero ${ }^{15}$, para Calvino não só é a origem da religião em geral (Institutio christianae religionis III, 2.), mas a partir daí é totalmente impossível um ateísmo. No entanto, permaneceu obscuro nestas duas posições, de Melanchthon e Calvino, como uma ideia neoplatônico-ciceroniana de Deus pode ser sistematicamente compartilhada com a teologia revelada. Em termos exatos, ambos explicavam a ideia de Deus da filosofia simplesmente como complementação para a teologia revelada, cuja autonomia e superioridade ambos tinham a intenção de considerar asseguradas.

Formalmente em uma direção semelhante, de acordo com a qual, portanto, a ideia filosófica de Deus não é mais compartilhada sistematicamente com a teologia, iam as tentativas da escolástica tardia espanhola, a qual o mais tardar desde a Synopsis Aristotelis Metaphysices de Nicolau Taurelo, do ano de 1596, também tiveram acolhida entre eruditos luteranos. Esta terceira perspectiva de efetivação na modernidade nascente se apoiava na tentativa de, diferentemente do que na Idade Média, que sempre se tinha sustentado na unidade da metafísica no sentido de Aristóteles, libertar a ideia filosófica de Deus de uma metafísica geral ${ }^{16}$. Assim Benedictus Perenius (falecido em 1610), em seu tratado Physicorum sive de principiis rerum naturalium, libri quindecim do ano de 1562, tinha distinguido entre uma prima philosophia ou scientia universalis, cujo objeto são as coisas mais gerais ou transcendentes, e a metafísica e teologia propriamente dita, cujo objeto então seriam as inteligências. Uma tal separação entre uma metafísica profana e uma teologia natural estava enfim também na base da compreensão de metafísica de Francisco Suarez (1548-1617).

De extraordinária significação para a modernidade nascente foi por fim o médico e teólogo espanhol Raimundo de Sabunde (falecido após 1436). Sabunde, com seu tratado Liber naturae sive creaturarum (terminado em 1436),

\footnotetext{
15 De natura deorum I 16, 43; 17, 45. Em Melanchthon estas passagens de Cícero importantes na história dos efeitos se tornaram sistematicamente determinantes primeiramente em seus Loci communes de 1521 no capítulo De lege (MELANCHTHON, 1952, p. 40-42). Melanchthon explica aqui, em conexão com Romanos 1.20 e 2.15, que na criação não só foram impressas leis naturais na mente das pessoas (em escritos posteriores as leges naturae são então os princípios práticos da filosofia moral), mas também princípios especulativos para as disciplinas teóricas, os quais ele chama de communia principia, koinai ennoiai ou simplesmente de $\pi \rho 0 \lambda \varepsilon \psi 1 \varsigma$.

16 Quanto a isso em detalhe, FEIEREIS, 1965.
} 
o qual desde a segunda edição de 1485 trazia o título Teologia naturalis ${ }^{17}$, tinha concedido à teologia filosófica uma posição preponderante até então desconhecida e afirmado ali que cada pessoa poderia através dessa ciência reconhecer sem esforço todas as verdades necessárias sobre Deus e sobre as pessoas humanas. Mas uma mediação sistemática entre ideias filosófica e teológica de Deus, e com isso uma nova unidade de filosofia e teologia, somente a renovação do conceito de philosophia perennis veio a oferecer, tal como apresentou o livro do ano de 1540 com esse mesmo nome do bibliotecário papal Agostino Steuco (1497-1548), assim como a edição dos cinco livros De antiquitatibus totius orbis do astrônomo caldeu Berosus, os quais o bibliotecário do Vaticano Annius de Viterbo (1432-1502) tinha editado no ano de $1498^{18}$. Steuco tinha elaborado o conceito de philosophia perennis de forma modelar para a modernidade nascente. Em sua base estava a convicção dos dois ramos de uma única revelação, de uma ciência unificada, que se desenvolve através da história enquanto translatio sapientiae. De acordo com ela a origem da sabedoria deve ser buscada nos dois filhos de Noé, é atestada na ciência egípcia e se explicita na filosofia grega como ciência dos princípios mais elevados. Uma tal concepção de uma ciência unificada, como a philosophia perennis ou a prisca philosophia apresenta, implica que esta simultaneamente sempre é uma teologia filosófica. "Philosophia perennis presupõe [...] a validade de uma teologia filosófica, ela parte da compatibilidade entre filosofia e teologia. Essa exigência de compatibilidade tem como consequência que a ciência só pode ser exercida de forma plenamente significativa no âmbito da revelação." (SCHMIDT-BIGGEMANN, 1995, aqui p. 2). Já na Antiguidade tardia ela tinha seus apologetas em Justino Mártir ${ }^{19}$, Clemente de Alexandria (Stromata) e Eusébio (Praeparatio evangelica). Comprovação para esta tese de que a origem de todo saber deveria ser buscada nos filhos de Noé tornamse agora, na modernidade nascente, entretanto, também fontes pagãs como as Antiquitates de Berosus ou do teólogo fenício Sanchuniaton. Este - assim já relatava Eusébio (Praeparatio evangelica, I 9,21-30.) - teria escrito um livro sobre a teologia dos egípcios ${ }^{20}$. Um papel especial desempenhou aqui também o Corpus hermeticum. O lendário Hermes Trismegisto era considerado, desde a

17 Para a história da impressão, cf. as referências em STEGMÜLLER, 1966, p. 11.

18 Detalhadamente sobre as Antiquitates de Viterbo assim como sobre De Perenni Philosophia de Steucos, SCHMIDT-BIGGEMANN, 1998, principalmente, p. 665-689.

19 Cf. quanto a isso o escrito - provavelmente não autêntico - Oratio ad Graecos.

20 Quanto a Sanchuniaton, que teria vivido na época da guerra de Tróia, cf. S. de SAINT BRISSON, 1667-1716, p. 1667-1716. 
tradução do Poimander por Marsilio Ficino (1433-1499) até a crítica filológica de Isaac Casaubon (1559-1614) ${ }^{21}$ como prova para uma doutrina da Trindade testemunhada também fora do Cristianismo ${ }^{22}$. Em tal situação histórica, em que agora, pois, também testemunhos pagãos entravam em jogo em favor da unidade e da generalidade da ideia de Deus no âmbito da discussão, ao menos dois problemas sistemáticos e históricos se colocavam para as discussões contemporâneas sobre filosofia da religião. Em que sentido a teologia pagã apresentava no âmbito da philosophia perennis uma antecipação da ideia cristã de Deus? E para além disso: Como se define a relação do conceito cristãotrinitário de Deus no contexto das duas outras grandes religiões? Se, pois, esta construção deveria ter validade, deveria ser exitosa a comprovação de que a Antiguidade não só tinha conhecido uma ideia teológica intercomunicável de Deus, mas até tinha formulado tal ideia ao menos enquanto uma ideia triádica.

\section{III.}

O primeiro esboço nessa discussão filosófica da religião - embora sem referência à philosophia perennis de Agostino Steuco - é apresentado pelo tratado De Veritate Fidei Christianae, do humanista espanhol Juan Luis Vives (1492-ca. 1544), próximo de Erasmo de Roterdã e de Tomás Morus ${ }^{23}$. No segundo capítulo do livro 2 Vives trata da doutrina cristã da Trindade (VIVIS, 1639, p. 214-232: De divina Trinitate) e ao lado da conhecida analogia triádica da mente, de Agostinho (Confessiones XIII, 11,12.), indica como exemplos pagãos para a trindade Zenão, que tinha caracterizado o $\lambda$ o $\gamma o \varsigma$ como fatum, necessitas e anima Iovis; o dito de Platão a respeito do boni ipsius filium (República 6); assim como Trismegisto, no qual se encontraria muito a respeito do Filho de Deus. ${ }^{24}$ De certo o mais influente tratado do século 16, entretanto, é apresentado pelo escrito filosófico da religião De la vérité de la religion chrestienne (MORNAEUS, 1581), de Philipp Mornaeus (Philippe de Mornay ou Philippe du Pessis-Mornay, 1549-1623), o qual também foi traduzido para o alemão (MORNAEUS, 1616), o holandês (MORNAEUS, 1602) e o italiano (MORNAEUS, 1612) por volta da virada do século - e isto destaca o seu sucesso. Além da já conhecida analogia triádica da mente,

21 Quanto a isto, cf. mais abaixo.

22 Assim está no livro 13 do Corpus hermeticum: "Tat: Dize-me ainda isto: Quem é aquele que produz o renascimento?" Hermes: "O filho de Deus, aquela uma pessoa, de acordo com a vontade de Deus.” COLPE; HOLZHAUSEN, 1997, p. 177.

23 VIVIS, 1639 (esta edição tenho diante de mim).

24 VIVIS, 1639, p. 221s. Cf. quanto a isso também ZEDLER, 1749/1963, p. 437-443. 
de Agostinho25, Mornaeus discute neste tratado detalhadamente a Trindade enquanto tema da prisca philosophia (Quod prisca philosophia Trinitatem docet \& confitetur) (MORNAEUS, 1616, p. 116-159). A apresentação das fontes da Antiguidade e patrísticas serve com isso para Mornaeus à finalidade da comprovação de que a doutrina da Trindade já teria sido atestada antes de Cristo, de que a forma pagã da Trindade, entretanto, teria sido corrompida por Aristóteles. Como testemunhas para essa concepção aparecem aqui, ao lado de eruditos antigos como Platão, Plutarco, Plotino, Proclo, Iambico, Hermes Trismgegisto também Agostinho26, Clemente de Alexandria (Stromata, III), Orígenes (Adversus Celsum, VI) e Cirilo de Alexandria (Adversus libros athei Iuliani, I). Em todo caso, aqui em sua referenciação historicizante agora aos Pais da Igreja, Mornaeus não visa um debate sistemático em torno das manifestações de Pais da Igreja em particular importantes para a doutrina da Trindade, mas sim uma comprovação - apologética - de que ao lado da filosofia antiga também os Pais da Igreja são testemunhas em favor da doutrina cristã da Trindade, como já o título do seu escrito deixa claro - os quais valem como testemunho da preeminência da religião cristã e como a explicação mais clara da prisca philosophia em relação ao Judaísmo e ao Islã. Pois isto é o seu objetivo declarado - citando da tradução alemã:

[...] unnd simbt also die ganze Griechische Philosophia beydes vor und nach unsers Herrn Christ Geburt mit der Christen Theologia von der Dreyfaltigkeit über ein/welches auch vor andere mehr gemerckt haben/und keinen ders liset/verborgen sein kann. ${ }^{27}$

Não entra em consideração, nesta interpretação da prisca philosophia, que portanto já sempre também implica a Trindade, para que então afinal ainda é necessária a teologia, se a Trindade enquanto um dos seus temas centrais é abarcada pela prisca philosophia. Em todo caso, a partir de agora a doutrina historicizante, filosófica da Trindade se torna em um ponto de virada e de

25 MORNAEUS, 1616, p. 64s: "Interim tamen agere, intelligere, velle, neque tres animae in nobis, neque tres vitae sunt; sed una anima, una vita; adeoque in unam essentiam juncta, ut eodem momento mens nostra in re aliqua agens rationem intelligit, unde eam velit aut non velit in quo quidem actu vis activa, \& intellectus, \& voluntas simul agunt \& concurrunt." De haeresibus (MPL 42, 21/50). Quanto à bibliografia, cf. ALTANER; STUIBER, 1978, p. 425.

27 Tradução do alemão antigo: “[...] e assim toda a filosofia grega, ambas, tanto a anterior quanto a posterior ao nascimento de nosso Senhor Cristo estão de acordo com a teologia cristã da Trindade, o que anteriormente também foi notado por outros, e a ninguém que leia pode estar obscuro." MORNAEUS, 1616, p. 155. 
sustentação da validade da philosophia perennis, como ela é explicitada desde Johann Heinrich Alsted enquanto theologia naturalis.

\section{IV.}

O editor do artigo Natürliche Theologie no Universallexicon (NATÜRLICHE, 1740, p. 1025-1939.) de Johann Heinrich Zedler sintetizou de forma abrangente a historiografia da modernidade nascente sobre teologia natural. Embora o autor se oriente na definição de teologia natural pelo conceito sistemático de Christian Wolff (1679-1754), que novamente tinha explicitado a theologia naturalis como metafísica ${ }^{28}$, aqui se encontra a história da teologia natural enquanto conceito guia da philosophia perennis. Após um louvor geral dos filósofos gregos Platão, Aristóteles e Cícero, e a referência às passagens clássicas de exemplificação da theologia naturalis em Romanos $1.19 \mathrm{~s}$, em que Paulo teria "demonstrado e apresentado claramente" (NATÜRLICHE, 1740 , p. 1029) a certeza e a necessidade da theologia naturalis, relata-se a respeito da posição dos Pais da Igreja em geral: "Alguns Pais da Igreja a elevaram tão alto que de fato se deve dizer: eles lhe atribuíram mais do que se lhe pode conceder" [...] (NATÜRLICHE, 1740, p. 1029). Na Idade Média a teologia natural teria decaído através da filosofia escolástica. Só no século 15 ela teria sido fundamentada novamente através de Raimundo de Sabunde, Agostino Steuco e no século 17 através de Johann Heinrich Alstedt:

Mas desde que o já mencionado Alstedius começou a escrever, e no ano de 1615 em quatro [livros] trouxe à luz uma theologiam naturalem, que de certo foi a primeira que veio à luz na Alemanha, e ao mesmo tempo deu à teologia natural a sua forma correta; [] (NATÜRLICHE, 1740, p. 1029.)

Alsted - assim conclui a historiografia de Zedler - teria fundamentado novamente uma grande quantidade destes tratados com sua theologia naturalis, e de fato não só entre eruditos reformados, mas também entre luteranos e [católicos] romanos.

28 WOLFF, 1739, Prolegomena. S. I. "Theologia naturalis est scientia eorum, quae per Deum possibilia sunt, hoc est, eorum, quae ipsi insunt, \& per ea, quae ipsi insunt, fieri posse intelliguntur." 
A teologia natural ${ }^{29}$ de Johann Heinrich Alsted (1588-1638) ${ }^{30}$ não representa apenas o primeiro esboço desta disciplina desde Raimundo de Sabunde, mas igualmente apresenta o primeiro debate a respeito do problema sistemático que o conceito guia da philosophia perennis acarreta para a teologia, principalmente em suas implicações da ideia triádica, respectivamente trinitária, de Deus enquanto ponto alto desta concepção filosófica. Decisivo para a comprovação da validade da philosophia perennis é sua antiguidade enquanto testemunho da continuidade de uma ideia natural de Deus que caracteriza a história desde a criação. Alsted enxerga isso fundamentado no fato de que ela é co-originária com a criação ${ }^{31}$. Para além disso, a sua utilidade seria atestada em autores antigos como Sócrates (XENOPHONTE. Memorabilia 1, 1), Platão ${ }^{32}$, Aristóteles ${ }^{33}$; em Pais da Igreja como Justino Mártir (De Monarchia), Clemente de Alexandria (Stromata), Eusébio (Praeparatio evangelica), Lactâncio ${ }^{34}$, João Crisóstomo (9. Homilia ao povo de Antioquia), Agostinho (De Trinitate 15,4.), assim como em Philipp Mornaeus.

Entretanto, em primeiro lugar fica claro que todo os exemplos trazidas por Alsted servem simplesmente para a comprovação da unidade e da generalidade de uma ideia natural de Deus, mas não da Trindade. Só que mesmo em relação a estas provas Alsted percebe estar confrontado com

29 ALSTED, Johann Heinrich. Theologia naturalis exbibens angustissimam naturae scholam; In qua creaturae Dei communi sermone ad omnes pariter docendos utuntur: Adversus Atheos, Epicureos, et Sophistas buius temporis, 1615/1623.

30 É surpreendente que esta primeira teologia natural quase não tenha sido objeto de investigação na Alemanha. Algumas referências se encontram em: WUNDT, 1939 p. 83; FEIEREIS, 1965, p. 19; SCHRÖDER, 1992, p. 715s (em todo caso o ano da primeira edição deve ser corrigido para 1615 [cf. p. 718, nota 1]); quanto a Alsted em geral, cf. STAEDTKE, 1993, p. 299-303 (com índice de obras e literatura); SCHMIDTBIGGEMANN, 1998, p. 689-701 (Alsteds apokalyptische Universalwissenschaft); SCHMIDT-BIGGEMANN, 2001, p. 392-448, 599-602; principalmente p. 427-434; HOTSON, 2000, o qual, entretanto, não aborda a philosophia perennis, mas se orienta de modo geral pelas teses de Francis Yates (Hermetismus) e Robert Merton (Calvinismus in seiner Funktion für die Konstruktion der Moderne). Estas duas tradições de pesquisa determinantes para o século 20 são detalhadamente discutidas em COHEN, 1994.

31 ALSTED, 1615/1623, p. 12: "Antiquitas tanta est, ut una cum huius mundi incunabilis sit orta."

32 ALSTED, $1615 / 1623$, p. 14. Aqui se encontra a tese platônica geral, "gratam de Deo famam in astris sparsam esse". Para além disso, Platão teria mostrado, no Timeu, que o demiurgo seria a origem e a disposição do universo.

33 Aqui se trata de uma prova da existência de Deus no âmbito da ideia aristotélica de movimento (Física, VIII).

34 Aqui Alsted de certo pensa nas Divinae institutiones, a obra principal de Lactâncio. Cf. quanto a tudo isso BENDER, 1983. 
quatro importantes ressalvas. A primeira ressalva está relacionada com a crítica à separação da teologia natural da metafísica geral, ou seja, com a dissolução da concepção da unidade e da generalidade da metafísica, assim como Pererius tinha apresentado na escolástica espanhola tardia e Taurellus no luteranismo. Pois a atestação da antiguidade e do proveito da Theologia naturalis demonstrado na Antiguidade e na Patrística está próximo da assunção de que esta simplesmente é novamente metafísica. Para Alsted as duas disciplinas não são somente distintas; a teologia natural nem mesmo é uma parte da filosofia, porque elas se distinguem tanto no finis quanto também no obiectum (ALSTED, 1615/1623, p. 13). Enquanto ontologia profana, se fosse além disso a metafísica trataria de Deus, dos anjos e das almas separadas de um modo errôneo (ALSTED, 1615/1623, p. 8). Uma vez que o tema da metafísica sejam os entes objetivos de uma forma geral, entre os quais não se coloca Deus, a ideia de Deus necessita de uma disciplina independente, a pneumática, respectivamente, a teologia natural ${ }^{35}$. A ideia de Deus, de acordo com Alsted, se funda muito mais naqueles princípios naturalizados do saber teológico, as notiones communes,

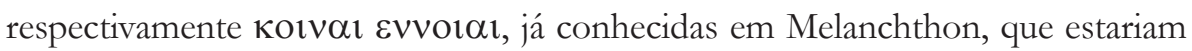
impressas por Deus na mente de todas as pessoas. E aqui opera como testemunho em favor da unidade e da generalidade de uma ideia natural de Deus também o argumento do consensus-gentium, que Cicero tinha apresentado no De natura deorum (I, 17). É claro que a naturalização deste princípio divino leva na prática a que sua negação - como já teriam ensinado Cícero, Sêneca e Avicena - arruína a própria natureza ${ }^{36}$.

Além da ressalva classificatória que está ligada à nova definição da metafísica como ontologia profana, entretanto, a tese da naturalização da ideia de Deus leva a duas outras ressalvas: uma teológica e uma epistemológica. A ressalva teológica consiste na assunção da teologia do pecado, de que a pessoa teria sido formada com uma falta de conhecimento de natureza negativa a respeito de todas as $\operatorname{coisas}^{37}$ e, consequentemente, também não poderia

35 ALSTED, 1615/1623, p. 29: "Cum enim Metaphysica sit sapientia generalissima, utique generalissimum, \& id quidem unicum, habebit subiectum. Non igitur Deum, tanquam ens singularissimum, non Angelos \& animam separatam, de quibus agit Pneumatica, considerabit."

36 ALSTED, 1615/1623, 37: "Sunt enim illae notitiae ita certae, ut contrariis earum positis, naturae destructio sequatur [...]. Quicunque Deum aut numen non agnoscit, non tantum ratione, sed \& sensu caret."

37 ALSTED, 1615/1623, p. 42: "1. Quia homo nascitur cum ignorantia negativa omnium rerum." 
possuir nenhum conhecimento de Deus. Com esta posição epistemológica resignada, no século 16 havia-se evocado a teologia paulina do pecado de Lutero repetidamente, com lugar proeminente para Matthias Flacius Illyricus no assim chamado colóquio de Weimar de 1560, no qual Flacius se deixou levar à fórmula, para ele mais tarde trágica, de que, através da queda, o pecado original tivesse se tornado a substância das pessoas não renascidas ${ }^{38}$. Alsted se associava nessa questão à posição da tradição que também Melanchthon tinha tornado frutífera para a teologia reformatória: a tese de uma imagem estrutural, permanente, de Deus no entendimento e na vontade, a qual como mostram Gênesis 1 e 2, assim como Romanos 2.15 - não se perderia através da queda no pecado. A ressalva epistemológica contra uma ideia naturalizada de Deus consiste na posição epistemológica aristotélica, "nada há no entendimento, que antes não tenha estado na experiência dos sentidos" (ALSTED, 1615/1623, p. 43). Esta posição, que em última instância resulta do realismo cognitivo aristotélico, leva à consequência de que também a ideia de Deus não pode ser inata à mente humana. Já em Melanchthon pertencia ao arsenal neoplatônico da crítica contra este realismo cognitivo aristotélico trazer à baila aquela antecipação inata daqueles conhecimentos que desde Epicuro foram chamados de $\pi \rho 0 \lambda \varepsilon \psi 1 \varsigma$, ou também os princípios matemáticogeométricos (duas vezes dois é igual a quatro), assim como princípios das condições formais da racionalidade (algo é ou não é), como argumento em favor do pressuposto apriorístico do saber, os quais simultaneamente poderiam ser elevados a testemunhos em favor da possibilidade de uma reivindicação de princípios naturais de Deus.

A quarta ressalva, enfim, que também se pode chamar de históricoreligiosa, não só coloca a questão sobre em que sentido a Trindade e a soteriologia pertencem a esta ideia natural de Deus testemunhada na Antiguidade $^{39}$, mas também se as pessoas da Trindade não seriam conhecidas de um modo natural ${ }^{40}$. Apesar disso é claro para Alsted que as pessoas da Trindade não podem ser reconhecidas com a razão natural, porque se trata de

\footnotetext{
38 Quanto a isso em detalhe: KROPATSCHECK, 1943; WEBER, 1940; PANNENBERG, 1991, Bd. 2, p. 241-245; cf. também as referências do autor (FRANK, 2003, capítulo III).

39 Aqui Alsted argumenta que os pagãos teriam assumido o pensamento trinitário dos judeus, assim como também Hermes Trismegisto e os primeiros teólogos egípcios e caldeus. (ALSTED, 1615/1623, p. 44: "Hermes Trismegistus, \& primi illi Aegyptiorum atque Chaldaeorum omnem suam scientiam a populo Dei hauserunt.")

40 ALSTED, 1615/1623, p. 146: "Trinitas personarum naturaliter nota est. Ergo illa hoc loco non fuit praetermittenda. Prob. antecedens."
} 
um mistério. Entretanto, há vestígios (vestigia) ou imagens (imagines) na criatura que permitem inferir uma semelhança triádica. Um exemplo importante é aqui o terno tomado de Agostinho das três faculdades da alma, intellectus, notitia, amor, as quais Alsted ao menos quer fazer valer como reflexo da Trindade ${ }^{41}$. Alsted tinha formulado os elementos essenciais da philosophia perennis para o gênero amplamente testemunhado da teologia natural do século 17 e $18^{42}$. Em seu centro está o conceito da unidade da ciência enquanto revelação original que foi obscurecida pela queda no pecado e a partir de agora seria reconquistada pela história da filosofia. No centro desta construção históricofilosófica esta a ideia de Deus, ou seja, a theologia naturalis. A ideia de Deus pertence, com isso, à configuração natural da mente humana, isto é, esta

41 ALSTED, $1615 / 1623$, p. 147s: "Inter eas excellit anima humana, cuius tres facultates, intellectus, notitia \& amor, aliquo modo exprimunt personas sacrosanctae Trinitatis, hoc nempe modo [...] Anima intelligit. Ergo \& Deus intelligit. Anima intelligendo gignit notitiam seu logon, id est, ratione. Ergo Deus intelligendo se, gignit etiam logon, sed infinitis modis perfectiorem. Praeterea, anima volendo producit amorem. Ergo \& Deus volendo producit amorem, sed infinitis modis perfectiorem. Omnis enim perfectio est in Deo. Cum vero nihil sit in Deo, quod non sit ipse Deus, sequitur, $\lambda$ oyov \& amorem illum esse eiusdem essentiae [...]. Quare sic concludamus: Licet Trinitas personarum ex luce naturae cognosci non possit, quippe quae est mysterium a seculis absconditum: tamen simile quippiam, quod alii Scholastici vocant vestigium, alii imaginem [...] in rebus creatis invenitur."

42 Esta concepção fundamental, com os Pais da Igreja enquanto apologetas da philosophia perennis, também se acha em dois outros escritos teológicos de Alsted: Praecognitorum Theologicorum libri duo: Naturam Theologiae explicantes, \& rationem studii illius plenissime monstrantes. Authore Joh. Henrico Alstedio, Frankfurt, 1614. Este escrito trata no livro I dos princípios da teologia, o livro II é uma doutrina teológica do método em que então também a relação da teologia com a filosofia é discutida e a duplex veritas é rejeitada. Aqui Alsted também trata dos motivos de crítica à filosofia de vários Pais da Igreja - dentre outros, das conhecidas manifestações de Tertuliano (Adv. Hermog. VIII [MPL 1, 204]: "Philosophorum ingeniis omnes haereses animari."; Adv. Marc. Lib. 1: "Philosophos vocat Patriarchas haereticorum.”). Alsted sintetiza a sua posição: "Patres non damnarunt Philosophiam simpliciter \& in genere, sed talem Philosophiam, quae nimirum paganissimis ethnicorum erat referta, quaeque Evangelicae de Christo veritati vim \& impedimentum adferebat. Philosophiam depraedatricem \& deceptricem damnant: sobriam infinitis locis commendant. Imo ipsi fuerunt Philosophie eximii." Também aqui a prisca theologia comprovaria pelo contrário a unidade e a generalidade da ideia de Deus (ALSTED, 1614, p. 55s). Deve-se fazer referência aqui também à obra escrita em Alba Julia, ALSTED, Turris Babel Destructa, hoc est Refutatio Argumentorum, quibus utuntur omnis generis gigantes ad stabiliendum confusionem in negotio religionis, Herborn 1639, um debate com as controvérsias teológicas de seu tempo, em que Alsted, com foco na crítica à Trindade dos Socinianos, defende a doutrina clássica da Trindade e o conceito de pessoa com o uso da exegese, da patrística e da filosofia (neoplatônica e hermética). 
teologia natural leva à naturaliz̧ação da ideia de Deus. Simultaneamente, esta é garantida pela antiguidade. Prova disso é a unidade e generalidade da ideia de Deus, como ela se estende pela história. Como cruzamentos para esta historicização da ideia de Deus operam assim - enquanto testemunhos extracristãos - as antigas teologias egípcia e caldeia, a filosofia grega, a tradição hermética e as posições dos Pais da Igreja, com o que estes - com exceção da doutrina da Trindade de Agostinho - são referidos mais num sentido geral enquanto testemunhos desta ideia de Deus. Naturalmente permaneceu controvertido em que sentido a doutrina da Trindade poderia ser tema da ideia de Deus no âmbito da philosophia perennis.

Alsted podia se reportar em seu esforço cuidadoso por uma doutrina especulativa da Trindade no contexto da philosophia perennis ao seu mestre Bartholomäus Keckermann (1573-1609). O próprio Keckermann tinha inferido a Trindade salvífica econômica - e esta era também a forma tradicional de procedimento da patrística e da escolástica - a partir da Trindade imanente ${ }^{43}$ e caracterizado Deus, enquanto primeiro e infinito Espírito, seguindo a João Damasceno, como "Supersubstância"44. Entretanto, a sua interpretação da Trindade imanente enquanto um modus existentiae de três modos ficou incompreensível, à medida que a tese ligada com isso, de que os modos de existência das três relações intra-trinitárias não seriam a própria essência de Deus, mas modi desta uma essência divina, poderia ao menos ser modalmente mal compreendida. No conjunto, entretanto, particularmente eruditos luteranos - sejam aqui citados somente Balthasar Meisner (1587-1626) ${ }^{45}$ e Johann Musäus (1613-1681) ${ }^{46}$ - mais tarde acusaram teólogos reformados de que eles argumentariam a respeito da Trindade não somente com a teologia revelada, mas também com base em considerações especulativas. E de fato parecia claro para eruditos luteranos que a doutrina da Trindade não era tema da prisca theologia. Entretanto, também eles sustentavam a elaboração histórica geral da philosophia perennis e a função apologética dos Pais da Igreja.

\footnotetext{
43 Quanto à doutrina da Trindade de Keckermanns, cf. o estudo do autor (FRANK, 2003, capítulo IV).

44 Dialectica, cap. IV. A Dialectica de João Damasceno é a primeira parte do extraordinariamente influente escrito De fide orthodoxa, ca. 740/750.

45 Aqui deve-se referir principalmente o escrito de Meisner Philosophia sobria, hoc est: pia consideratio quaestionum philosophicarum, in controversiis theologicis, quas Calviniani moverunt Orthodoxis, subinde occurrentium, Wittenberg, 1611.

46 O escrito de Musäus é De usu principiorum rationis et philosophiae in controversiis theologicis, Jena, 1644.
} 


\section{V.}

Também para esta posição, segundo a qual a Trindade não poderia ser um tema da prisca philosophia no âmbito da elaboração histórica da philosophia perennis, era possível se reportar, além de aos filósofos antigos, aos Pais da Igreja - à medida que esta temática fosse efetivamente discutida na teologia natural ${ }^{47}$. Assim, se encontra na teologia natural de Stephan $\mathrm{Klotz}^{48}$ uma discussão detalhada dos partidários e dos opositores da teologia trinitária enquanto tema da prisca philosophia. Entre os partidários da doutrina trinitária encontram-se Raimundo Lullus, Nicolau Cusanus (Cribratio Alkorani II, 3, 94-96), Juan Luis Vives (De Veritate fidei christianae, II, 2), Pedro Abelardo (Theologia Summi boni - Introdução ao livro 2), Philipp Mornaeus (1616, I, 5), Bartholomäus Keckermann (Systema theologiae I, 3) e Theodor Zwinger (Theatrum vitae humanae, Vol. 5, L. 4). Entre os opositores a uma doutrina especulativa da Trindade, Klotz refere Ricardo de São Victor (De trinitate, I, 4), João Gerson (Alphabet, 13. lit.) e Tomás de Aquino (Summa theologiae I, qu. 31, A. 1) a fim de com base nisso formular a sua própria posição crítica: De fato haveria - como entende Agostinho - alguns vestigia trinitatis na criação, mas não seria possível que estes pudessem ser comprovadas a partir de fundamentos convincentes e irrefutáveis do entendimento. E esta teria sido também a opinião de Hilário (De trinitate, I, 7) e de João Damasceno (De fide orthodoxa, I, 9). Klotz se reporta em sua própria posição crítica a Martim Lutero, que em seu comentário a Gênesis 18 teria distinguido entre o probare e o ornare, chegando à conclusão de que a Trindade das pessoas não poderia ser comprovada suficientemente através de razões do entendimento ${ }^{49}$.

47 A temática da doutrina da Trindade não aparece efetivamente desta forma na teologia natural de Balthasar Cellarius (1614-1671). Cf. a esse respeito seu escrito: Epitome Theologiae Philosophicae seu naturalis, Juxta Aristotelem \& Autorem L. de mundo concinnata, Scholasticorum doctrina illustrata, \& cum Scripturis collata. Cum indice duplici. Opera \& studio M. Balthasaris Cellarii Francohusani Thuringi, Jena, 1661. Cellarius, nascido em Rothleben, no condado de Schwartzburg, havia estudado em Jena e Wittenberg, em Helmstedt sob Georg Calixt. Mais tarde ele se tornou superintendente e professor em Helmstedt.

48 KLOTZ, Stephan. Pneumatica sive Theologia Naturalis: h.e. De Deo ut Natura cognoscibilis est Tractatio Theologica Et Scholastica; E Scripturis B. Patrum \& Priscorum Philosophorum scriptis ac sana ratione concinnata; Praefica est Praefatio Noticiis naturalibus \& adjecti in fine indices [...], Rostock, 1640. Stephan Klotz (1606, em Lippe, Vestfalia - 1668) tinha estudado em Marburg e desde 1627 era professor de física, metafísica, ética e lógica em Rostock. Cf. quanto a isso ZEDLER, 1737, p. 971-973.

49 KLOTZ, 1640, p. 376: “[...] non tamen ita, quod per has rationes sufficienter probetur Trinitas personarum.” 
Lutero teria aqui defendido uma posição semelhante a de Tomás de Aquino. Semelhantemente teológico-crítico parece ser o balanço da ideia triádica de Deus sob autores não cristãos que Klotz discute detalhadamente em relação aos conhecidos apologetas Orígenes, Lactâncio, Steuco, Mornaeus e Trismegisto. Mesmo que haja exemplos de pensamento triádico entre pagãos, isto simplesmente espelharia uma impressão difusa da Trindade que poderia antes ser mal compreendida em termos sabelianos ou triteístas ${ }^{50}$.

Mas Klotz mantinha, junto com outros eruditos luteranos, a tese central referente a uma naturalização da ideia de Deus, cerne da philosophia perennis que se estende na história, apesar de diversas críticas teológicas ${ }^{51}$.

50 KLOTZ, 1640, “[...] quid si non tres personas, sed tria nomina propter diversos respectus Deo tribuerint, ut post Sabellius? Aut tres reipsa Deos essentialiter distinctos introduxerint, ut post fecerunt Tritheitae [...]."

51 Nisso a crítica vinha por exemplo de parte [católico-]romana, como no caso de Roberto Bellarmino, que em suas Disputationes de controvesiis christianae fidei, no capítulo "De gratia et libero arbitrio", capítulo 2 , tinha defendido a posição de que "[...] adeoque nullam Dei notitiam naturaliter ad evidentiam posse pervenire [...] non posse de Deo quicquam cognosci sine speciali adjutorio gratia." Mas a crítica a uma ideia naturalizada de Deus também vinha da parte socianista, em função de seu rigoroso princípio escriturístico; assim em Fausto Sozzino: "[...] nullam in homine naturalem Dei cognitionem esse, ne quidem ante lapsum, ne dum post; neque plus extra Scripturas de Deo cognosci posse." Klotz cita esta posição teológica crítica de Fausto Sozzino. Praelect. theol., Cap. 2, p. 2. Ainda Wolff tomou esta posição como ocasião para o seu próprio debate sobre o âmbito temático da teologia natural. Cf. WOLFF, Christian. Theologia naturalis methodo scientifica pertractata. Pars Prior, integrum systema complectens, qua existentia et attributa Dei a posteriori demonstrantur, Prolegomena \23, 24. Seja simplesmente referida aqui uma das mais abrangentes histórias da religião sobre os pagãos, de Daniel Clasen (1622-1678): Danielis Clasenii Theologia Gentilis seu Demonstratio qua probatur Gentilium Theologiam, (ceu tenebras) Deos, Sacrificia \& alia ex fonte Scripturae (ceu luce) originem traxisse in tres partes divisa \& indicibus exornata. Clasen, nascido em Lüneburg, estudo em Helmstedt, reitor da escola em Magdeburg, professor de direito, ética e política, desde 1661 professor de direito em Helmstedt, que além disso também elaborou um escrito pouco considerado De religione politica, Helmstedt, 1673, tinha não só apresentado de modo abrangente o esquema histórico-teológico reconhecido de forma geral da philosophia perennis, mas também o tinha incrementado através de exemplos na religião dos tártaros, no Islã (Corão, Sutra 2,159) e até na religião dos Brâmanes. Aqui já influíram os novos conhecimentos de outras religiões, por exemplo os que o pregador holandês Abraham Rogers (falecido em 1649), da costa de Coromandel em Paliacate (Companhia das Índias Orientais), tinha compartilhado com o ocidente a respeito do Bramanismo. Seu escrito Gentilismus reseratus surgiu em 1651, em Amsterdã. Sua tradução alemã é: Offene Thür zu dem verborgenen Heydenthum, nebst einem andern Tractätgen, Asiatisches, Africanisches und Americanisches Heydenthum, genannt, Nürnberg, 1665. 


\section{VI.}

O ponto alto e de virada desta construção histórica da philosophia perennis com o seu centro na - naturalmente controversa com relação à tríade - teologia natural, que portanto não estaria exemplificada somente em forma cristã - no Novo Testamento e nos Pais da Igreja -, mas também fora do Cristianismo, foi representado pela primeira filosofia da religião na modernidade nascente: a que o neoplatônico inglês Ralph Cudworth (16711688) com o seu True Intellectual System of the Universe tinha apresentado no ano de $1678 .{ }^{52}$ Mas diferentemente do que nos aqui discutidos teólogos da teologia natural desde Alsted, cuja relação com os Pais da Igreja permanecia mais exterior, enquanto que estes eram absorvidos in cumulo em favor da prisca theologia, sem tematizar as próprias tensões sistemáticas que sem dúvida caracterizavam posições entrementes contrapostas na questão referente a uma ideia natural de Deus na doutrina dos Pais da Igreja, era intenção declarada de Cudworth conquistar terreno sistemático para a sua filosofia da religião no debate com os Pais da Igreja. Isto está em conexão principalmente com a sua teologia neoplatônica, cuja tendência já desde os primeiros tempos dos Pais da Igreja sempre tinha sido latente ou abertamente subordinacionista. No mais, em seu tempo, esta perspectiva da filosofia da religião de Cudworth está diante do desafio tanto da crítica à ideia natural de Deus simplesmente (o materialismo de Thomas Hobbes) quanto também da crítica da Trindade enquanto doutrina contrária à razão e à Escritura (deísmo $)^{53}$.

A filosofia da religião de Cudworth - isso preciso aqui ao menos referir brevemente - se constitui a partir de duas perspectivas sistemáticas: uma histórico-religiosa e filosófico-religiosa e outra lumino-metafísica ou epistemológica. A teoria metafísico-ideal de Cudworth - para iniciar com esta segunda perspectiva - consiste em sua tentativa de transformar o inatismo inocente, como ele caracterizou a ideia naturalizada de Deus em sua assunção de princípios naturais do saber teológico, em uma teoria disposicional do conhecimento. O alvo da sua metafísica das ideias é a comprovação de que cada conhecimento, isto é, também o conhecimento de Deus, não apresenta simplesmente uma percepção de princípios do conhecimento meramente naturais e pré-existentes, mas sempre uma realização originária

\footnotetext{
52 Quanto à filosofia da religião de Ralph Cudworth, cf. para detalhadamento o estudo do autor (FRANK, 2003, capítulo VI: aqui se encontra também em detalhe a literatura a respeito do neoplatônico inglês).

53 CUDWORTH, 1678, p. 558-632.
} 
da mente humana. A perspectiva histórico-religiosa e histórico-filosófica consiste na philosophia perennis, portanto naquela concepção que se manifesta historicamente de uma única e original revelação, a qual estaria obscurecida pela queda no pecado e que deve ser novamente reerguida pela via da história da filosofia e pela da história da religião. E aqui se encontram então todas as conhecidas estações desta história da filosofia: A aceitação de que os egípcios possuíam a sabedoria, os exemplos pré e extra-cristãos desta sabedoria em Berosus e em Sanchuniaton e sem esquecer, como testemunho mais importante, Hermes Trismegisto. Entretanto, importante para a compreensão de Cudworth é que ele interpreta a philosophia perennis de forma extensivamente neoplatônica e trinitária. Ele fundamenta isto não somente com a referência à conhecida passagem no Corpus hermeticum (XIII, 177), mas através da interpretação neoplatônica da Trindade divina que já estava cunhada pelos conceitos guia triádicos de bondade, unidade e terno ${ }^{54}$. Cudworth chega em sua concepção até mesmo ao ponto de explicar a teologia aristotélica trinitariamente. Assim ele interpreta a teoria aristotélica da causa eficiente do movimento no sentido da alma do mundo platônica como testemunho para a proximidade em relação ao esquema triádico do neoplatonismo ${ }^{55}$. Com esta explicação neoplatônica da doutrina da Trindade na perspectiva do platonismo cristão, Cudworth, entretanto, está exatamente diante dos mesmos problemas sistemáticos que justamente já em Atanásio tinham levado à superação do subordinacionismo na doutrina da Trindade. Pois por um lado esta interpretação percorria a emanação da plenitude divina de $\varepsilon v$, vous e $\psi v \chi \eta$, tal como o oferecia o esquema neoplatônico da Trindade, em sentido de um subordinacionismo trinitário imanente. Por outro lado, com a derivação do terno a partir da unidade da essência divina, que a partir do Parmênides (137c-145.) de Platão levantava a questão da inclusão da variedade do mundo no uno divino, era difícil de determinar o limite entre Deus e criatura. Este segundo problema poderia também ser interpretado

54 Cf. quanto a isso em detalhe: BEIERWALTES, 1979, p. 165-239; BEIERWALTES, 1985, p. 205-220; BEIERWALTES, 1978, principalmente p. 18-24; SCHMIDT-BIGGEMANN, 1998, principalmente p. 99-109; PANNENBERG, Bd. 1, 1988, principalmente p. 300-315.

55 CUDWORTH, 1678, v. 1, p. 413: "The immediate efficent cause of which motion also, no less according to Aristotle than Plato, seems to have been a mundane soul; however Aristotle thought not so fit to make this soul a principle; in all probability, because he was not so well assured of the incorporeity of souls, as of minds or intellects." 
como panteísmo. Diante do pano de fundo deste problema sistemático duplo se encontra agora o debate de Cudworth com os Pais da Igreja ${ }^{56}$.

De acordo com Cudworth, Platão teria reconhecido uma Trindade de hipóstases universais e divinas que possuíssem a natureza dos princípios57. Tomado de forma exata, trata-se do esquema triádico do neoplatonismo. Acima da alma do mundo (yuch), que seria a causa de todo movimento no mundo, estaria a mente ou o intelecto (nouV), o genuíno demiurgo ou o arquiteto construtor do mundo. Para além disso, Platão ainda teria reconhecido como hipóstase superior o ser simplíssimo e absoluto que ele chamaria de $\tau$ o $\varepsilon v$, em contraposição a toda diversidade do mundo. A partir daí ocorreria uma correspondência admirável entre a filosofia platônica e o Cristianismo, à

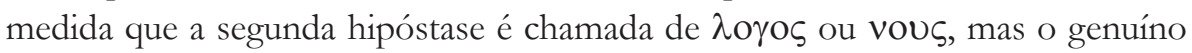
autor do mundo é o demiurgo ou arquiteto do mundo ${ }^{58}$. Nesta interpretação Cudworth se refere à posição subordinacionista tanto de Tertuliano (Adversus Praxeam 8; 22; 29.) como também de Orígenes (Comm. In Johann. II, 3 MPG 14, 109D; De principiis I, 3,7), que tinham falado bastante da primeira pessoa da divindade como fons deitatis. É claro que uma tal posição, que em Codworth é chamada de the fountain of the Godhead ${ }^{59}$, pode ser entendida facilmente como um subordinacionismo imanente no sentido de uma emanação da divina plenitude na Trindade. Isto, na Patrística, estava naturalmente na esteira de Ário, que tinha negado a co-eternidade e divindade do Filho enquanto segunda pessoa da Trindade. Cudworth, por isso, se remete ao seu oponente Atanásio ${ }^{60}$ para com ele argumentar contra Ário que este é incorretamente chamado de platônico. O que Cudworth quer provar é claro: Nenhum platônico no mundo

56 Cudworth também debateu detalhadamente com a crítica dos Pais da Igreja ao politeísmo pagão $(1678$, v. 1, p. 278-284). Mas no presente ponto trata-se exclusivamente do problema sistemático da doutrina neoplatônica da Trindade de Cudworth.

57 CUDWORTH, 1678 ' v. 1, p. 406: “[...] that Plato himself really asserted such a Trinity of Universal und Divine Hypostases, which have the nature of Principles."

58 CUDWORTH, 1678, p 407s: "Wherein we cannot but take notice of an Admirable Correspondency, betwixt the Platonick Philosophy and Christianity, in that the Second Hypostasis of both their Trinities (called also sometimes logoV by the Platonists, as well as nouV) is said to be the Immediate Cause of All things; and the Demiurgus, the Architect, Maker or Artificer of the Whole World."

59 CUDWORTH, 1678' v. 1, p. 407: "The fountain of the Godhead [...]. The King of All things, about whom are All things, and for whose sake are All things, and the Cause of all Good and Excellent Things."

60 Epistola de sententia Dionysii episcopi Alexandrini, I, 567. Detalhadamente quanto a este debate sistemático entre Atanásio e Ário: PANNENBERG, 1988, BD. 1, principalmente p. 295-305. 
jamais negou a eternidade desta mente que é a segunda hipóstase da Trindade ${ }^{61}$. Cudworth argumenta de modo semelhante com respeito à terceira hipóstase, a alma do mundo platônica. Aqui ele se remete por sua vez a Plotino (Eneadas 5, 3, cap. 2.), que tinha distinguido entre uma alma do mundo mundana e uma supramundana, a qual não seria a forma do mundo corpóreo, mas o arquiteto do mundo. O objetivo de comprovação da argumentação é claro: Também assim seria evidente, de acordo com os referidos princípios de Atanásio, que nenhuma das três hipóstases da Trindade platônica são criaturas, mas todas são divinas e incriadas ${ }^{62}$.

Apesar disso, Cudworth acrescenta que o problema principal de uma doutrina neoplatônica da Trindade é o subordinacionismo, uma vez que, a partir de uma compreensão neoplatônica geral, haja uma dependência da segunda e da terceira hipóstases em relação à primeira, de modo que não se possa falar de uma igualdade absoluta ${ }^{63}$. Mas, em todo caso, mesmo uma maioria dos Pais da Igreja nos primeiros três séculos - Cudworth menciona Justino, Irineu, Tertuliano, Clemente de Alexandria, Orígenes e Dionísio de Alexandria - tinham ensinado um tal subordinacionismo gradual. Isso tornaria o "erro subordinacionista" dos platônicos ao menos tolerável. Para além disso, a subordinação gradual de uma doutrina neoplatônica da Trindade só deveria ser entendida internamente à Trindade (ad intra), não em relação à criação (ad extra). Apesar da eternidade igualitária ad extra seria necessário existir, entretanto, uma certa subordinação ad intra ${ }^{64}$. A conclusão desta

${ }_{61}$ CUDWORTH, 1678, v. 1, p. 575: "To conclude, no Platonist in the World, ever denied the Eternity of that Nous or Universal Mind, which is the Second Hypostasis of their Trinity [...]."

62 CUDWORTH, 1678, v. 1, p. 577: "And thus according to the forementioned Principle of Athanasius, non of these Three Hypostases of Plato's Trinity, were Creatures, but all of theme Divine and Uncreated."

63 CUDWORTH, 1678, p. 592: "First, because the Platonists dream'd of no such thing at all, as One and the Same Numerical Essence or Substance, of the Three Divine Hypostases. And Secondly, because though they acknowledged non of those Hypostases to be Creatures, but all God; yet did they assert an Essential Dependence of the Second and Third upon the First, together with a certain Gradual Subordination; and therefore no Absolute Co-equality. And this is the true reason, why so many late Writers, have affirmed Platonism to Symbolize with Arianism, and the Latter to have been indeed nothing else but the Spawn of the Former [...]."

64 CUDWORTH, 1678, p. 600: "Wherefore when Athanasius and the other Orthodox Fathers, writing ageinst Arius, do so frequently assert the Equality of all the Three Persons, this is to be understood in way of opposition to Arius only, who made the Son to be Unequal to the Father as eteroousion, of a different Essence from him, One being God and the other 
discussão é: o cristão platônico agora concluiria que a Trindade ortodoxa da Igreja antiga tardia concordaria com a Trindade platônica, e isso enquanto não existisse nenhuma "mono-ousidade", só uma única essência sob três conceitos ou modi, mas três hipóstases ou pessoas. Entretanto, também na igualdade de essência e na consubstancialidade das três hipóstases divinas se mostraria concordância (CUDWORTH, 1678, p. 592). Mas não se pode deixar de reconhecer que o preço desta interpretação é o subordinacionismo imanente da Trindade da teologia pré-nicena, ariana.

No que diz respeito ao segundo problema sistemático de uma doutrina neoplatônica da Trindade, à questão da natureza da alma do mundo, que em função de sua relação com o mundo pode facilmente ser interpretada de forma panteísta, também é claro para Cudworth que isto facilmente poderia levar a uma "cosmolatria" ou "mundolatria", porque de fato ela não pode determinar claramente a distinção entre criador e criatura ${ }^{65}$. Entretanto, de acordo com Cudworth isto é uma incompreensão da teologia platônica. Pois, na segunda carta a Dionísio, Platão falaria dos deuses eternos como o primeiro, o segundo e o terceiro, os quais ele compreende como princípios de todas as coisas, isto é, como hipóstases da sua trindade divina ${ }^{66}$. Em todo caso, - pensa Cudworth - também Eusébio teria compreendido isto assim (Praeparatio evangelica I, 20).

Abstraindo-se por ora da doutrina subordinacionista imanente da Trindade e da interpretação ao menos problemática da alma do mundo platônica, a filosofia da religião de Cudworth, no entanto, também em dois outros aspectos apresenta uma mudança na compreensão da philosophia perennis que também teve consequências para a função da patrística nesta elaboração histórica. Por um lado isso está ligado com a superação da naturalização da

a Creature; they affirming on the contrary, that he was Equal to the Father, as omoousioV, of the same Essence with hin; that is, as God and not a Creature, Notwithstanding which Equality, there might be some Subordination in them, as Hic Deus and Haec Persona (to use Petavius his Language) This God and that Person."

65 CUDWORTH, 1678, p. 570: "Wherefore we may conclude, that this Platonick or rather Pseudo-Platonick Trinity, which confounds the Differences betwixt God and the Creature, and that propably in favour of the Pagan Polytheism and Idolatry, is nothing so agreable to Reason itself, as that Christian Trinity before described, which destinctly declares how far the Deity goes, and where the Creature beginns [...]."

${ }^{66}$ CUDWORTH, 1678, p. 572: "By such Eternal Gods he there meant doubtlesse that to prwton, and to doiteron, to triton, that First, and Second, and Third; which in his Second Epistle to Dionysius, he mages to be the principles of All things; that is, his Trinity of Divine Hypostases, [...]." 
ideia de Deus que tinha se desenvolvido a partir da teoria do saber natural dos princípios teológicos na teologia natural da modernidade nascente. Tais tentativas da superação de um inatismo inocente, natural, não se encontram apenas na metafísica da luz de Cudworth, mas no conjunto das discussões a respeito da metafísica das ideias em conexão com René Descartes. Refira-se aqui somente os tratados de Nicolas Malebranche (1638-1715), Recherche de la vérité, Paris 1674-1675, e Antoine Arnauld (1612-1694), Des vrayes et des fausses idées, Colônia, 1683. ${ }^{67}$ A crítica do conhecimento que John Locke (1632-1704) apresentou em seu Essay Concerning Human Understanding no ano de 1689 rejeitou por fim qualquer forma de um saber inato, natural ou apriorístico, e com isso também uma ideia natural de Deus (FRANK, 2003, cap. VII).

Ao lado desta superação de uma naturalização da ideia de Deus que tinha se desenvolvido a partir da crítica do conhecimento no Iluminismo nascente, entretanto, na mesma medida a crítica filológica teve consequências abrangentes para a historicização e com isso para a elaboração histórica da teologia natural. O erudito reformado Isaac Casaubon (1559-1614), em uma controvérsia que tinha surgido através dos Annales ecclesiastici do historiador e mais tarde cardeal Cesare Baronio (1538-1607), publicados nos anos entre 1588 e 1602, tinha apresentado uma gama de argumentos históricos e filológicos ${ }^{68}$ que mostravam que o Corpus hermeticum era um testemunho posterior a Cristo, e com isso colocavam em questão o seu caráter de exemplo importante para a antiguidade da philosophia perennis ${ }^{69}$. No mais, Cudworth procurou enfraquecer esta crítica com sua tese histórico-filosófica de uma subsistência da verdade que perpassaria a história, isto é, apesar de toda falsificação ao menos uma verdade a embasaria, e ela teria dado subsistência a esta narrativa da história ${ }^{70}$. Mas em princípio esta crítica histórico-filológica tinha revelado o caráter mistificador da elaboração histórica da philosophia perennis.

O papel dos Pais da Igreja enquanto apologetas da teologia natural, respectivamente da filosofia da religião na modernidade nascente, terminou no conjunto em um triplo dilema sistemático. A crítica filológica - em

${ }_{67}$ Cf. quanto a isso também as referência no estudo do autor (FRANK, 2003, cap. VII).

68 De rebus sacris et ecclesiasticis exercitationes, Geneva, 1655.

69 A respeito da crítica histórico-filológica ao Corpus hermeticum, em detalhes GRAFTON, 1983, p. $78-92$.

70 CUDWORTH, ${ }^{1678}$, v. 1, 320. Em detalhe, cf. o estudo do autor (FRANK, 2003, cap. VI). No mais, a crítica histórico-filológica de Casaubons já está presente na teologia natural de Stephan Klotz $\left({ }^{1640}\right.$, p. 53), embora não adquira significação sistemática para uma perspectiva própria da teologia natural. 
posição de destaque Isaac Casaubon quanto ao caráter extra-cristão do Corpus hermeticum - tinha desmontado a historicização da philosophia perennis e com isso também a ideia de uma unidade e generalidade da ideia de Deus. A crítica do conhecimento de John Locke, por sua vez, tinha mostrado o caráter obsoleto da naturalização da ideia de Deus, tal como ela se expressava na teoria do saber teológico inato, apriorístico (koinai ennoiai, notitiae naturales, notiones communes, common notions). A crítica da metafísica de Immanuel Kannt, por fim, colocou de forma ainda mais fundamental a questão pela possibilidade ou impossibilidade de uma theologia naturalis ou de uma filosofia da religião no contexto da metafísica clássica. Com os dois primeiros dilemas sistemáticos, também a função da patrística enquanto apologética da teologia natural ou da filosofia da religião tinha se tornado supérflua. $\mathrm{Na}$ metafísica e na crítica da metafísica do século 18 - o que já se vê com uma olhada na teologia natural de Christian Wolff, que de novo é extensamente elaborada enquanto metafísica - seu papel tinha se tornado simplesmente caduco. Consequentemente, ela nem aparece mais no contexto dessas discussões.

\section{Referências}

Obras referidas pelo ano de publicação e título

ALSTED, Johann Heinrich. Praecognitorum Theologicorum libri duo: Naturam Theologiae explicantes, \& rationem studii illius plenissime monstrantes. Authore Joh. Henrico Alstedio, Frankfurt, 1614.

ALSTED, Johann Heinrich. Theologia naturalis exhibens augustissimam naturae scholam; In qua creaturae Dei communi sermone ad omnes pariter docendos utuntur: Adversus Atheos, Epicureos, et Sophistas huius temporis. Frankfurt (?), 1615 (Segunda edição: Hanau 1623).

ALSTED, Johann Heinrich. Turris Babel Destructa, hoc est Refutatio Argumentorum, quibus utuntur omnis generis gigantes ad stabiliendum confusionem in negotio religionis, Herborn, 1639.

ALTANER, Berthold; STUIBER, Alfred. Patrologie. Leben, Schriften und Lehre der Kirchenväter, 8. Aufl. Freiburg, Basel, Wien, 1978.

BARONIO, Cesare. De rebus sacris et ecclesiasticis exercitationes, Geneva, 1655.

BEIERWALTES, Werner. Denken des Einen. Studien zur neuplatonischen Philosophie und ihrer Wirkungsgeschichte, Frankfurt 1985.

BEIERWALTES, Werner. Platonismus im Christentum, Frankfurt, 1998. Philosophische Abhandlungen 73 . 
BEIERWALTES, Werner. Proklos. Grundzüge seines Denkens. Frankfurt/M., 1979.

BENDER, Albrecht. Die natürliche Gotteserkenntnis bei Laktanz und seinen apologetischen Vorgängern. Frankfurt/M., 1983.

BURGER, Christoph. Jian Gerson. In: KÖPF, Ulrich (ed.) Theologen des Mittelalters. Darmstadt, 2002.

CELLARIUS, Balthasar. Epitome Theologiae Philosophicae seu naturalis, Juxta Aristotelem \& Autorem L. de mundo concinnata, Scholasticorum doctrina illustrata, \& cum Scripturis collata. Cum indice duplici. Opera \& studio M. Balthasaris Cellarii Francohusani Thuringi, Jena, 1661.

CICERO, Marcus Tullius (HEINE, Alexander, ed.). Vom Wesen der Götter. Essen : Phaidon o. J. Bibliothek der Philosophie 16. 1990.

CLASEN, Daniel. Danielis Clasenii Theologia Gentilis seu Demonstratio qua probatur Gentilium Theologiam, (ceu tenebras) Deos, Sacrificia \& alia ex fonte Scripturae (ceu luce) originem traxisse in tres partes divisa \& indicibus exornata, Frankfurt, Leipzig, 1684.

COHEN, H. Floris. The Scientific Revolution. A Historiographical Inquiry. Chicago, 1994.

COLPE, Carsten; HOLZHAUSEN, Jens (ed.) Das Corpus Hermeticum Deutsch. Stuttgart, Bad Cannstatt, 1997. Calvis Pansophiae 7,1.

CUDWORTH, Ralph. True Intellectual System of the Universe [TIS]. London : Richard Royston, 1678.

DIETER, Theo: Der junge Luther und Aristoteles. Eine historisch-systematische Untersuchung zum Verhältnis von Theologie und Philosophie. Berlin, New York, 2001. Theologische Bibliothek Töpelmann 105.

EBELING, Gerhard. Disputatio de homine, 3 Bde. Tübingen, 1977-1989.

ERNST, Wilhelm. Gott und Mensch am Vorabend der Reformation. Eine Untersuchung zur Moralphilosophie und -theologie bei Gabriel Biel. Leipzig, 1972. Erfurter theologische Studien, n. 28.

FEIEREIS, Konrad. Die Umprägung der natürlichen Theologie in Religionsphilosophie. Ein Beitrag zur deutschen Geistesgeschichte des 18. Jahrhunderts. Leipzig, 1965. Erfurter theologische Studien, n. 18.

FLASHAR, Helmut. Grundriss der Geschichte der Philosophie. Die Philosophie der Antike, 3. Basel; Stuttgart, 1983.

FRANK, Günter. Die theologische Philosophie Philipp Melanchthons (1497-1560). Leipzig, 1995. Erfurter theologische Studien, n. 67.

FRANK, Günter. Die Vernunft des Gottesgedankens. Religionsphilosophische Studien zur frühen Neuzeit. Stuttgart; Bad Cannstatt, 2003.

GRAFTON, Antony. Protestant versus Prophet: Isaac Casaubon on Hermes Trismegistus. Journal of the Warburg and Courtauld Institutes, n. 46, 1983, p. 78-92. 
HOFFMANN, Daniel. Pro duplici veritate Lutheri, Magdeburg, 1600.

HONNEFELDER, Ludger. Der zweite Anfang der Metaphysik. Voraussetzungen, Ansätze und Folgen der Wiederbegründung der Metaphysik im 13./14. Jahrhundert. In: BECKMANN, Jan P. e. al (ed.) Philosophie im Mittelalter, 2. Aufl. Hamburg 1996.

HOTSON, Howard. Johann Heinrich Alsted (1588-1638). Between Renaissance, Reformation, and Universal Reform. Oxford, 2000. Oxford Historical Monographs.

JUNGHANS, Helmar. Die probationes zu den philosophischen Thesen der Heidelberger Disputation Luthers im Jahr 1518. In: LUTHERGESELLSCHAFT. Luterjahrbuch, n. 46, Vandenhoeck \& Ruprecht, 1979, p. 34-57.

KLOTZ, Stephan. Pneumatica sive Theologia Naturalis: h.e. De Deo ut Natura cognoscibilis est Tractatio Theologica Et Scholastica; E Scripturis B. Patrum \& Priscorum Philosophorum scriptis ac sana ratione concinnata; Praefica est Praefatio Noticiis naturalibus $\&$ adjecti in fine indices [...], Rostock, 1640.

KROPATSCHECK, H. Das Problem der theologischen Anthropologie auf dem Weimarer Gespräch zwischen Flacius Illyricus und Victorinus Strigel. Tese. Göttingen, 1943.

MEISNER, Balthasar. Philosophia sobria, hoc est: pia consideratio quaestionum philosophicarum, in controversiis theologicis, quas Calviniani moverunt Orthodoxis, subinde occurrentium. Wittenberg, 1611.

MELANCHTHON, Phillip. Loci communes rerum theologicarum seu hypotyposes theologicae. 1521. In: STUPPERICH, Robert, (ed.) Melanchthon Studium Ausgabe [MSA], Bd. II/1. Bertelsmann, 1952, p. 1-163.

MORNAEUS, Philipp Della verita della religione christiana: Contra gli Athei, Epicurei, Pagani, Giudei, [...] / Da Philippo Mornayo [...] Trad. da franc. Po Francesco Perrotto. Salmur, 1612.

MORNAEUS, Philipp. Bybel der nature: dat is, Vande Waerheyt der christelijcke Religie teghens de Atheisten, Epicureen, Heydenen, Joden, Mahumedisten [...] / Door Philips Mornay, Heere van Plessis. Nu eerst verduijscht met verclaringen [...] Door Ioannem Halsbergium, [...]. Amsterdam, 1602.

MORNAEUS, Philipp. De la vérité de la religion chrestienne: Contre les Athées, Epicuriens, Payens, Juifs, Mahumedistes, \& autres Infideles. Antwerpen, 1581.

MORNAEUS, Philipp. De veritate religionis christianae, oder, daß die christliche Religion, die rechte wahre Religion sei. Ein Buch, so [...] zu disen unseren zeiten hochnotwendig, wider die Atheos, [...] wider die Epicurer, Heyden, Juden, Mahumedisten [...] / Erstlich von Philippo Mornaeo [...] in Frantzösischer und Lateinischer Sprach beschriben, jetzo aber, [...] in die Teusche Sprach gebracht, durch Manesse Oppenriedern. Rotenburg auff der Tauber, 1616.

MOSTERT, Walter: Luthers Verhältnis zur theologischen und philosophischen Überlieferung. In: JUNGHANS, Helmar, (ed.). Leben und Werk Martin Luthers von 1526-1546. Festgabe zu seinem 500. Geburtstag, 2. Aufl, Bd. 1. Berlin, 1985, p. 347-368. 
MUSÄUS, Johann. De usu principiorum rationis et philosophiae in controversiis theologicis, Jena, 1644.

NATÜRLICHE Theologie. In: ZEDLER, Johann Heinrich. Großes vollständiges UniversalLexicon aller Wissenschaften und Künste, Bd. 23. 1740, p. 1025-1939.

PANNENBERG, Wolfhart. Systematische Theologie, Bd. 1, Göttingen 1988.

PANNENBERG, Wolfhart. Systematische Theologie, Bd. 2, Göttingen, 1991.

ROGERS, Abraham. Offene Thür zu dem verborgenen Heydenthum, nebst einem andern Tractätgen, Asiatisches, Africanisches und Americanisches Heydenthum, genannt. Nürnberg, 1665.

SAINT BRISSON. Dissertation sur l'authenticité [...] de Sanchoniathon. In: MINGE, Jacques Paul. Patrologiae Cursus Completus. Series Graeca [MPG]. V. 21, 1667-1716.

SCHMIDT-BIGGEMANN, Wilhelm. Enzyklopädie und Philosophia perennis. In: EYBL. Franz M. (ed.) Enzyklopädien der Frühen Neuzeit. Beiträge zu ihrer Erforschung. Tübingen, 1995, p. 1-18.

SCHMIDT-BIGGEMANN, Wilhelm. Philosophia perennis. Historische Umrisse abendländischer Spiritualität in Antike, Mittelalter und Früher Neuzeit, Frankfurt/M., 1998.

SCHMIDT-BIGGEMANN. Die Schulphilosophie in den reformierten Territorien. In: HOLZHEY, Helmut; SCHMIDT-BIGGEMANN, Wilhelm (ed.) Grundriss der Geschichte der Philosophie. Die Philosophie des 17. Jahrhunderts. Bd. 4. Das Heilige römische Reich deutscher Nation Nord- und Ostmitteleuropa. Basel, 2001, p. 392-448, 599-602.

SCHRÖDER, Winfried. Religion bzw. Theologie, natürliche. In: RITTER, Joachim. Historisches Wörterbuch der Philosophie [HPW], Bd. 8. Schwabe, 1992, p. 713-727.

SPEER, Andreas; WEGENER, Lydia (ed.) Meister Eckhart in Erfurt : Internationale Tagung vom 25. bis 28. September 2003 anlässlich des Meister Eckhart-Gedenkjahres, das die Stadt Erfurt für 2003. Berlin; New York: Walter de Gruyter, 2005.

STAEDTKE, Joachim: Artigo Alsted, Johann Heinrich. In: KRAUSE, Gerhard; MÜLLER, Gerhard. Theologische Realenzyklopädie [TRE], Bd. 2. 2. Aufl. Berlin : De Gruyter, 1993, p. 299-303.

STEGMÜLLER, Friedrich. Einleitung des Neudrucks der Theologia naturalis von Raimundus Sabundus. Stuttgart, Bad Cannstatt, 1966.

VIVIS, Ioannis Lodovici. Valentini, De Veritate Fidei Christianae, Libri V. In quibus de Religionis nostrae fundamentis, contra Ethnicos Iudaeos, Agarenos, sive Mahumetanos, \& perverse Christianos plurima exactissime disputantur. Basel, 1543 (primeira edição), Köln 1568, Leiden 1639, Lyon 1639.

VOET, Leon. The Plantin Press (1555-1589). A Bibliography of the Works printed and published by Christoper Plantin at Antwerp and Leiden, Bd. 4. Antwerpen, 1982.

WEBER, Hans Emil. Reformation, Orthodoxie und Rationalismus, Bd. I/2, Gütersloh, 1940 . 
WEISCHEDEL, Wilhelm. Der Gott der Philosophen, Bd. 1. München 1979.

WOLFF, Christian. Theologia naturalis methodo scientifica pertractata. Pars Prior, integrum systema complectens, qua existentia et attributa Dei a posteriori demonstrantur. Autore Christiano Wolfio, Frankfurt; Leipzig, 1739, p. 1-24 (Nova impressão: Hildesheim; New York, 1978).

WUNDT, Max. Die deutsche Schulmetaphysik des 17. Jahrhunderts, Tübingen, 1939. Heidelberger Abhandlungen zur Philosophie und ihrer Geschichte 29.

ZEDLER, Johann Heinrich. Grosses vollständiges Universallexikon, Bd. 15, Leipzig, Halle, 1737.

ZEDLER, Johann Heinrich. Grosses vollständiges Universallexikon, Bd. 49. Leipzig; Halle, 1746. Nova Impressão: Graz, 1963.

\section{Obras clássicas mencionadas em codificação convencional.}

ABELARDO, Pedro. Theologia Summi boni.

AGOSTINHO, Aurélio. Confissões.

Agostinho, Aurélio. De Trinitate.

ARISTOTELES. Física.

ARISTOTELES. Metafísica.

ATANASIO. Epistola de sententia Dionysii episcopi Alexandrini.

CALVINO, João. Institutio christianae religionis [ICR]

CÍCERO. De natura deorum.

CIRILO DE ALEXANDRIA. Adversus libros athei Iuliani.

CLEMENTE DE ALEXANDRIA. Stromata.

CRISÓSTOMO, João. Homilia ao povo de Antioquia.

EUSÉBIO. Praeparatio evangelica.

DAMASCENO. João. Dialectica.

DAMASCENO. João. De Fide orthodoxa.

GERSON, João. Alphabet.

HILÁRIO. De trinitate.

JUSTINO MÁRTIR. 1. Ap. 46; 2. Ap

JUSTINO MÁRTIR. De monarchia. 
KECKERMANN, Bartholomäus. Systema theologiae.

LUTERO, Martim. M. Luther, Werke, Kritische Gesamtausgabe, Weimar, 1833ss [WA].

MELANCHTHONS, Philipp. BRETSCHNEIDER, Carol. Gottl.; BINDSEIL, Henricus Ernestus (Ed.). Corpus Reformatorum: Philippi Melanthonis opera quae supersunt omnia [CR]. Brunsviga: Schwetschke, 18??.

MINGE, Jacques Paul. Patrologiae Cursus Completus. Series Graeca. [MPG].

MINGE, Jacques Paul. Patrologiae Cursus Completus. Series Latina. [MPL].

NICOLAU CUSANUS. Cribratio Alkorani.

ORIGENES. Adversus Celsum.

ORIGENES. De principiis.

ORIGENES. Commentaria in evangelium Iohannis [MPG 14].

PLATÃo. Parmênides.

PLATÃO. República.

PLATÃO. Timeu.

PLOTINO. Eneadas.

RICARDO DE SÃO VICTOR, De Trinitate.

TERTULIANO. Adversus Hermogenem. VIII [MPL 1, 204]

TERTUliAnO. Adversus Marcionem.

TERTUliAnO. Adversus Praxeam.

TERTUliAnO. De Praescriptionibus Adversus Haereticos. In: E. Dekkers, J. G. P. Borleffs, R. Willems, R. F. Refoulé, G. F. Diercks, A. Kroymann (eds.) CORPUS Christianorum, Series Latina [CCL].

TOMÁS DE AQUINO. Summa Theologiae.

TRISMEGISTO, Hermes. Corpus hermeticum.

XENOPHONTE. Memorabilia.

VIVES, Juan Luis. De Veritate fidei christianae libri V...

ZWINGER, Theodor. Theatrum vitae humanae.

Tradução: Eduardo Gross. 